\title{
Dental emergencies in public health services: what is the role of the Dental Surgeon?
}

Open Access

\author{
Leonardo Essado Rios ${ }^{a}$, Maria Goretti Queiroz ${ }^{b}$
}

\begin{abstract}
OBJECTIVE: To assess the opinions of Brazilian dental surgeons (DS) about their roles in Public Emergency Dental Services (PEDS)

METHODS: A cross-sectional study was conducted with an intentional sample of 44 DS who worked at the PEDS in a large municipality in the central-western region of Brazil, in 2013. To collect data we designed, pretested and applied a self-administered questionnaire with Likert scale assertions about the DS duties, referral of patients and execution of dental procedures in PEDS. Post-hoc tests revealed an instrument's reliability of $91 \%$.

RESULTS: As their main duty, DS pointed out providing relief to patients' complaints in cases of dental pain and trauma. Regarding referral of patients, they considered typically that they should refer to services at a higher complexity level those patients exhibiting infections in advanced stages under risk of disseminations. Most of them disagreed with performing dental restorations in emergency consultations, while the majority stated that they should mainly perform intraoral abscesses drainage, alveolitis and haemorrhage treatment.

CONCLUSION: To provide pain and trauma relief to patients was pointed out by DS as their key role in PEDS, as well as to refer at-risk patients to high-level complexity services and to perform procedures aimed at solving emergency situations, instead of providing restorative treatment to patients.
\end{abstract}

Key words: Public Health Dentistry; Dental Health Services; Emergencies; Public Health Policy; Dental Care

\section{Urgências odontológicas em serviços públicos de saúde: qual o papel do Cirurgião-Dentista?}

\section{RESUMO}

OBJETIVO: Avaliar a opinião de cirurgiões-dentistas (CD) brasileiros sobre o papel deles em Serviços Odontológicos Públicos de Urgência (SOU)

METODOLOGIA: Um estudo transversal foi realizado com uma amostra intencional de $44 \mathrm{CD}$ que trabalhavam em SOU em um município de grande porte na região centro-oeste do Brasil, em 2013. Para coletar os dados foi elaborado, pré-testado e aplicado um questionário autoexplicativo com escala Likert e asserções sobre as atribuições dos CD, encaminhamento de pacientes e execução de procedimentos odontológicos nos SOU. Testes posteriores revelaram uma confiabilidade deste instrumento de $91 \%$.

RESULTADOS: Como sua principal atribuição, os CD apontaram que devem buscar aliviar as queixas dos pacientes em casos de dor e trauma dental. Com relação ao encaminhamento de pacientes, eles consideraram tipicamente que deveriam referenciar para serviços de maior complexidade aqueles pacientes com infecções em estágios avançados com risco de disseminação. Muitos deles discordavam com a realização de restauração dental nas consultas de urgência, enquanto que a maioria considerou que deveria executar drenagem intraoral de abscessos, tratamento de alveolite e hemorragia.

CONCLUSÃO: Os CD reconheceram que prover alívio aos pacientes com dor e trauma é o seu principal papel nos SOU, além de referenciar pacientes de risco para unidades de maior complexidade e realizar procedimentos clínicos voltados à resolução de situações de urgência, ao invés de prover procedimentos restauradores aos pacientes.

Palavras-chave: Odontologia em Saúde Pública; Serviços de Saúde Bucal; Urgências; Políticas Públicas de Saúde; Assistência Odontológica a Department of Dentistry, Federal Institute of Education Science and Technology of Goiás, Brazil Department of Oral Health, School of Dentistry, Federal University of Goiás, Brazil

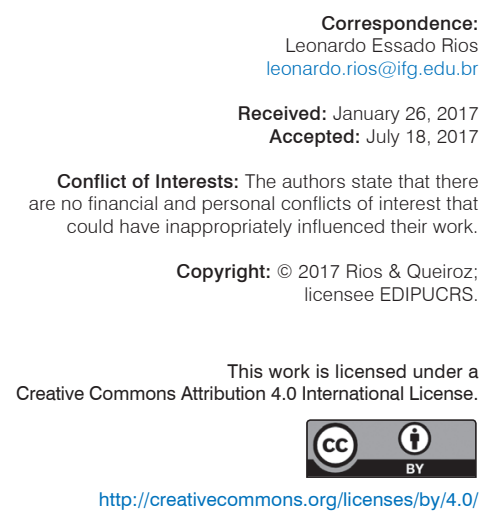




\section{INTRODUCTION}

Attention to dental emergencies demands clinical actions that aim to overcome in an agile way, acute traumatic, infectious or haemorrhagic events, among others, which produce pain and/or discomfort in the oral cavity. It's encompassed the need for the removal of the cause, attenuation of pain symptoms and reestablishment of impaired functions [1,2].

In Brazil, the National Oral Health Policy, as well as other public policies - National Primary Care Policy, National Emergency Care Policy - advocate that such occurrences are priority conditions, which require resolute procedures. The policies also reinforce the relevance of specific public services for emergency care in various health areas $[1,3,4]$.

Strategies for coping with conditions that require immediate attention in the Unified Health System (SUS) include the Emergency Public Dental Services (PEDS) [5-10]. These types of services provide prompt care to dental emergencies, representing an important part of the oral health services system, which is especially reachable to low level social vulnerable people who can't access regular dental treatment $[5,6,11,12]$. As well, PEDS work on a basis of out-of-hours care and fill a gap left by regular services which are normally closed during weekends, holidays and at night [10].

Some studies have evaluated PEDS in different contexts. The investigations aimed at: reasons for patient's demanding emergency care and conducts performed by the dental surgeon (DS) $[13,14]$, socio-demographic profile of the population served $[6,11]$, characteristics and functioning of services [10] and patient satisfaction [7].

The views of the oral health professionals have also motivated some studies. A survey conducted in Brazil addressed the perception of managers and DS about the PEDS, identifying prominent issues such as the profile of care, structural and organizational aspects [5]. The same authors explored the perception of PEDS' DS regarding the interface between these services and others in primary health care [9]. However, the vision of PEDS' professionals about what they understand as being their roles in these services has not yet been explored. Thus, the aim of this study was to assess the opinions of Brazilian DS about their roles in PEDS.

\section{METHODOLOGY}

A cross-sectional study was carried out in Goiânia a municipality of about 1.3 million inhabitants located in the Central-western region of Brazil. The Municipal Health Department had ten emergency dental services (PEDS) in the year of the present study, which made up the research universe.

Criteria of inclusion: all the DS who effectively worked at the municipal PEDS by the time of data collection $(n=65)$ were invited to participate (non-probabilistic intentional sample). Criteria of exclusion: professionals in temporary or occasional condition in the service were excluded $(n=4)$.

The variables studied were the characteristics of the participants - gender, age and professional qualification and their opinions about their roles in the PEDS: (i) their duties, (ii) type of patients that they should attend at PEDS or refer to more complex services and (iii) clinical procedures that they should or shouldn't perform in the PEDS.

Data were collected through a questionnaire responded by professionals at their workplaces, between February and April 2013. This instrument was designed to be used in our study, evaluated by external oral health researchers, pretested among DS professionals and presented a post-hoc reliability of $91 \%$. Detailed information about the process of elaboration and reliability analysis of this instrument can be found in a previously published study [10].

In the instrument, the question regarding participants' opinions about their duties in the service contained six assertions; the question about referral of patients, 11 assertions; and the question about clinical procedures was composed by 15 assertions. Each assertion was answered using a five-point Likert scale: full disagreement, disagreement, neutrality, agreement and full agreement. Statistical descriptive analysis was performed using SPSS statistics 17.0 software.

This research was approved by the Research Ethics Committee of the Hospital Materno Infantil de Goiás (Protocol 26/2012). The Municipal Health Department authorized the research and the participants freely consented to participate and signed a consent form.

\section{RESULTS}

Of the 65 professionals invited to participate in the study, 44 answered the questionnaire (Response rate $=70 \%$ ). Two participants $(4.5 \%)$ did not report gender, 18 (40.9\%) were men and $24(54.6 \%)$ were women. The age groups were: 25-34 years $(n=15,34.1 \%), 35-49$ years $(n=21,47.7 \%), 50$ 59 years $(n=6,13.6 \%)$ and 60 years or more $(n=2,4.5 \%)$. Regarding professional qualification, the main specialties reported were Prosthesis and Public Health (both with $\mathrm{n}=15$, $34.1 \%)$. Eight participants $(18.2 \%)$ reported on the area of Endodontics.

Table 1 shows the results on the opinion of dentists in relation to their duties as PEDS professionals. The assertions "Alleviate pain complaints" and "Attend patients with dental trauma" received the highest rates of agreement. Meanwhile, the assertion "Meet any patients' demands" received the highest rates of disagreement.

Table 2 shows the results of the participants' opinion regarding emergency patients who should be referred from PEDS to more complex health units. Major statements of agreement occurred in the assertions: "Patients presenting advanced stage infections at risk of dissemination" and "Patients with abscesses requiring extraoral drainage". The lowest agreement was found in the statement "Patients with dental-alveolar trauma". 
Table 1. Opinion of dental surgeons about their duties in the municipal public emergency dental service

\begin{tabular}{|c|c|c|c|c|c|}
\hline \multirow{2}{*}{ Assertions } & \multicolumn{5}{|c|}{ Concordance: $\mathrm{N}(\%)^{*}$} \\
\hline & FD & D & 1 & A & FA \\
\hline 1. Alleviate pain complaints & - & - & - & $8(18)$ & $36(82)$ \\
\hline 2. Attend patients with dental trauma & - & - & - & $15(34)$ & $29(66)$ \\
\hline 3. Solve complaints of discomfort to the patient & $5(11)$ & $12(27)$ & $6(14)$ & $10(23)$ & $11(25)$ \\
\hline $\begin{array}{l}\text { 4. Perform temporary restorations on teeth without pulp involvement } \\
\text { (so that the patient can seek scheduled care) }\end{array}$ & $2(4)$ & $3(7)$ & $6(14)$ & $21(48)$ & $12(27)$ \\
\hline $\begin{array}{l}\text { 5. Solve aesthetic problems that can be cured with direct restorations } \\
\text { (e.g. fractured anterior teeth or drop filling) }\end{array}$ & $2(4)$ & $5(11)$ & $3(7)$ & $22(50)$ & $12(27)$ \\
\hline $\begin{array}{l}\text { 6. Meet any patients' demands (e.g. complaints of "tooth demanding } \\
\text { cleaning" or "caries requiring filling") }\end{array}$ & 16 (36) & $21(48)$ & $3(7)$ & $2(4)$ & $2(4)$ \\
\hline
\end{tabular}

* FD: full disagreement; D: disagreement; I: indifference; A: agreement; FA: full agreement.

Table 2. Opinion of dental surgeons on patients in emergency situations who should be referred from the emergency dental service to more complex units

\begin{tabular}{|c|c|c|c|c|c|}
\hline \multirow{2}{*}{ Assertions } & \multicolumn{5}{|c|}{ Concordance: $\mathrm{N}(\%)^{*}$} \\
\hline & FD & D & 1 & A & FA \\
\hline 1. Patients presenting infections in advanced stages at risk of dissemination & - & - & - & $12(27)$ & $32(73)$ \\
\hline 2. Patients with abscesses requiring extra-oral drainage & - & $9(21)$ & - & $11(25)$ & $24(54)$ \\
\hline 3. Patients with Temporomandibular joint dislocation & $1(2)$ & $13(30)$ & $1(2)$ & $9(21)$ & $20(45)$ \\
\hline 4. Patients with severe hypertension (above 179: $109 \mathrm{mmHg}$ ) & $2(4)$ & $13(30)$ & - & $11(25)$ & $18(41)$ \\
\hline 5. Uncompensated diabetic patients & $1(2)$ & $14(31)$ & $3(7)$ & $13(30)$ & $13(30)$ \\
\hline 6. Patients with heart disease & $2(4)$ & $21(48)$ & $4(9)$ & $10(23)$ & $7(16)$ \\
\hline 7. Patients seropositive for HIV or AIDS & $8(18)$ & $23(52)$ & $3(7)$ & $7(16)$ & $3(7)$ \\
\hline 8. Patients with hepatitis & $8(18)$ & $17(39)$ & $4(9)$ & $9(20)$ & $6(14)$ \\
\hline 9. Patients with oral mucosal burns & $3(7)$ & $16(37)$ & $4(9)$ & $14(31)$ & $7(16)$ \\
\hline 10. Patients with mental disorders & $2(4)$ & $10(23)$ & $6(13)$ & $16(36)$ & $10(23)$ \\
\hline 11. Patients with dental-alveolar trauma & $6(14)$ & $27(62)$ & $2(4)$ & $5(11)$ & $4(9)$ \\
\hline
\end{tabular}

* FD: full disagreement; D: disagreement; I: indifference; A: agreement; FA: full agreement.

The opinion of dentists regarding the procedures they should perform in PEDS is presented in Figure 1. There was greater agreement with the assertions: "Treatment of alveolitis", "Haemorrhage", "Drainage of intraoral abscess" and "Prescription of medication", while "Dental restoration" obtained the lowest agreement.

Figure 1. Opinion of dental surgeons about the procedures that should be performed in the municipal public emergency dental service

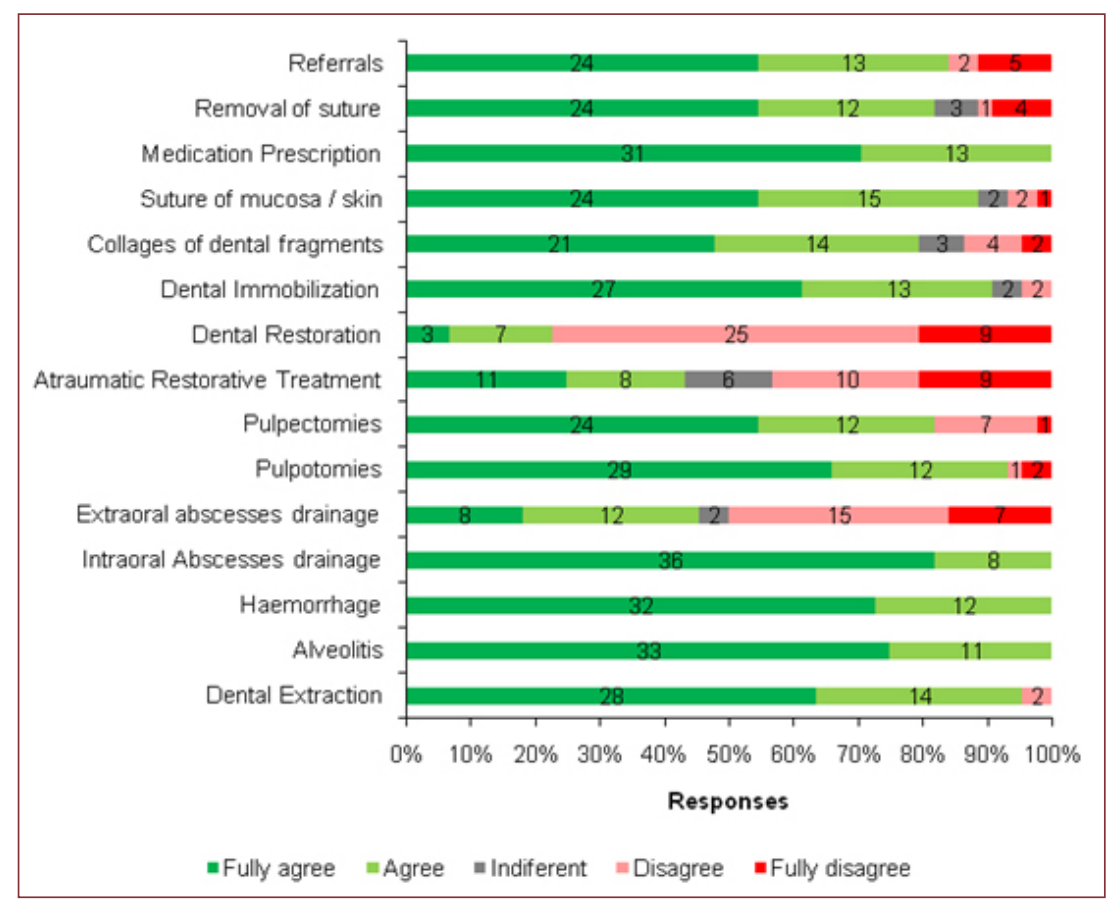




\section{DISCUSSION}

Our findings indicate that dentists in PEDS know how to clearly distinguish cases of dental emergency from those situations that are elective, which do not require immediate attention and whose care is not perceived as one of their duties. The professionals mostly disagree that they are supposed to perform dental restorations in these services. As well, they realize that their role basically involves promoting immediate relief to people suffering from pain or dental trauma. This finding is coherent since previous studies indicate that the most common dental emergencies are those of painful origin, usually due to caries, endodontic problems, periodontal diseases or dental trauma [15-18].

The results of the most recent national oral health survey in Brazil show that the prevalence and severity of pain in the population is a concern and a frequent cause of demand for dental care in general [19]. Toothache still causes negative impact on individuals' quality of life [20-22], therefore a greater orientation for pain relief and trauma care in PEDS is in fact expected [1-3].

In many cases, toothache leads the patient to ask for dental extractions, with the aggravating fact that this procedure is usually less expensive than restorative procedures involving endodontics and unitary prostheses [23]. Thus, exodontias are very common in this type of service $[9,10]$ and despite of the importance of conservative treatment prioritizing the maintenance of the dental element [24], the procedure can be adequately and resolutely performed in PEDS, e.g. in situations such as vertical fractures of the root. In the present study, dental extraction was pointed out by most of DS as one of the procedures they are supposed to perform in PEDS.

However, the DS discernment on emergency patients that should be referred from the PEDS to more complex health units showed very divergent results and a lack of evidence based practice. For example, many of them disagree that patients with heart disease must be referred to higher complexity services, even when evidence shows that emergency procedures for more severe patients with heart disease - such as new infarcts (less than 06 months after acute myocardial infarction) - need to be referred to hospital care [25]. In addition, it is usual to postpone elective dental treatments in decompensated diabetic patients. When in emergent needs, however, prompt care is expected, paying attention to additional care $[25,26]$, but the professionals surveyed tended to refer these patients instead of offering prompt care.

Also, cases of more severe odontogenic infection with a tendency to spread to other organs and tissue spaces should be carefully evaluated, and the risk of systemic involvement should be identified. More severe cases should be referenced and attended more safely in hospital settings with greater resources and specialized professionals, such as bucomaxillofacial surgeons, preventing obstruction of upper airways and/or septicaemia [27]. In this topic, there was a fine agreement among the DS in the PEDS.
The absence of consensus in the answers regarding most of the items surveyed suggests that there is a lack of a good definition about caring or referring distinct types of patients in these services. In Goiânia, the public oral health care system is composed by basic care services (Family Health Strategy), PEDS, services of middle complexity (Dental Specialties Centres) and high complexity services (in public hospitals). There's a referral and contra-referral system in which patients are supposed to have full care depending on their oral health demands. However, in PEDS this referral system is lacking and a collapse between PEDS and the municipal oral care system is noticed [10], what may have influenced the DS views on this topic.

It should be noted that in the daily routine of dental emergency services, conducts of professionals who only prescribe medications to patients, without performing the recommended care ceasing to intervene effectively in the focus of the infection, which is not considered adequate, aren't rare. A survey conducted in a similar health service identified that most of the patients attended presented pain associated with pulpitis or localized dental abscess, and only a minority showed signs and / or symptoms of a possible disseminated infection. Approximately $75 \%$ of patients with pulpitis received antibiotic prescription incorrectly [28]. Excessive prescriptions may be explained by the scarcity of resources in PEDS, but also due to the lack of a protocol with clinical and pharmacological guidelines [10].

Another study, carried out in the PEDS of the same municipality where the present study was conducted, also demonstrated the restriction of dental emergency care in children only to prescriptions, without any effective clinical intervention [8]. It is emphasized that the professional who attends these services must be able to treat dental odontalgias, abscesses, dental trauma, haemorrhages and alveolitis. The dentist should also be able to treat oral lesions and to correctly use the available drug therapy, seeking to act in a resolute manner [2].

In addition, DS should be prepared to adequately conduct emergency situations in which the patient presents some special need, requiring specific technical knowledge and preparation. So, it is important to note that emergency dental care for patients with special needs (PEN) is essential, what requires a special approach and a specific protocol. In several PEN cases, emergency procedures are not contraindicated, depending on the risk assessed. However, when there is a substantial risk, a multidisciplinary team approach is required in order to stabilize the patient's clinical status before starting the planned procedures [25]. An ideal clinical care in a dental emergency requires careful evaluation and anamnesis, based on qualified listening and dialogue, in order to know the patient, establish an adequate diagnosis and resolution, valuing their well-being and their autonomy [2].

Another relevant aspect is the fact that, in an emergency consultation, even if the professional does not necessarily have the commitment to complete the patient's treatment, but rather to overcome the urgent situation, it is desirable 
to seek an improvement in the condition of oral health until the patient can access the scheduled care. Examples are the procedures of temporary and/or definitive restoration in cases of deep caries [2].

We identified that dental procedures which received the highest agreement among the DS participating in this study were those that may be effective in emergency situations and require a basic technical preparation from the professional. For instance, the dental restoration procedure is not always necessary aimed at the relief of an urgent situation and the drainage of extraoral abscesses demands a more complex technical knowledge and is not a frequent situation in clinical practice.

Meanwhile, despite being a restorative technique and not directed at emergency relief, Atraumatic Restorative Treatment (ART) did not obtain as much disagreement as conventional dental restoration, probably because it is a simpler restorative technique, although it requires specific knowledge of the dental surgeon.

A previous study found positive attitudes and good knowledge about ART among public service dentists in the same municipality where the present study was conducted [29]. This reveals that it may be interesting to invest in performing this technique in the PEDS, especially because PEDS professionals have been inclined to consider "performing temporary restorations so that the patient seeks scheduled care" as one of their duties.

The National Oral Health Policy suggests, as a strategic element for the organization of emergency dental services, the application of less complex technologies, such as ART [1]. Using cavity preparation performed without anaesthesia, removal of the carious tissue with manual instruments and sealing of the cavity with ionomeric cements, ART can be understood as an approach to reduce caries activity and, possibly, painful symptoms, until a definitive restoration via programmed care at the health unit is possible [30].

The limitation of this study concerns to its intentional sampling of 44 respondents, which does not allow generalising the results beyond the population in question. However, as strong points, we highlight the inclusion criterion which considered only effective professionals of PEDS, the good response rate and especially the way our questionnaire was elaborated, contemplating important stages with the involvement of researchers and professionals in services [10]. All these points give a good consistency to our findings.

Therefore, this research is important because it represents an exploratory approach regarding the role of professionals in the attention to dental emergencies in the Unified Brazilian Health System. To our best knowledge, there is no official document or study where one can find clearly what is the role of the DS in PEDS, thus this study can be useful to inform and support changes in the protocols for these types of services.

Finally, in addition to subsidize public policies regarding dental emergencies, our study raises some questions for further investigations. For example, there is a need for actions and research aimed at the training and continued education of DS in PEDS, given the need for immediate and decisive intervention in case of acute problems. Equally important is the creation and implementation of evidence based protocols to guide the work of dentists in PEDS, improvements in the referral system and, mainly, a good offer of services on the level of basic oral health care in order to prevent dental emergencies.

\section{CONCLUSION}

DS who work at the researched PEDS state their key role as to provide relief to patients, especially in cases of toothache or dental trauma. Generally, there is a lack of consensus among them regarding their conducts, both in relation to referral of patients and to the execution of clinical procedures. However, they mostly tend to agree on referring at-risk patients to high-complexity services and perform procedures typically aimed at solving emergency situations rather than restorative procedures. The findings suggest the need for better investments in the qualification of these professionals and in the organization of this type of service.

\section{REFERENCES}

1. Brasil. Ministério da Saúde. Diretrizes da Política Nacional de Saúde Bucal. Brasília: Ministério da Saúde; 2004. http://dab.saude.gov.br/ portaldab/biblioteca. php?Conteudo=publicacoes/pnsb

2. Brasil. Ministério da Saúde. Secretaria de Atenção à Saúde. Departamento de Atenção Básica. Acolhimento à demanda espontânea: queixas mais comuns na Atenção Básica. Brasília: Ministério da Saúde; 2012. 290 p (Cadernos de Atenção Básica n. 28, Volume II). http://189.28.128.100/ dab/docs/publicacoes/cadernos_ab/caderno_28.pdf

3. Brasil. Ministério da Saúde. Política Nacional de Atenção Básica. Brasília Ministério da Saúde; 2012. http://dab.saude.gov.br/portaldab/biblioteca. php?conteudo=publicacoes/pnab

4. Brasil. Ministério da Saúde. Política Nacional de Atenção às Urgências. 3 ed. ampl. Brasília: Ministério da Saúde; 2006. 256 p. http://187.17.2.102/ fhs/media/files/samu/politica nacional de atencao as urgencias.pdf

5. Austregésilo SC, Leal MCC, Góes PSA, Figueiredo N. An Evaluation of the Urgent Dental Services Units (UDS): The View of Health Managers, Supervisors and Professionals. Pesq Bras Odontoped Clin Integr. 2013;13(2): 161-9

6. Cassal JB, Cardozo DD, Bavaresco CS. (2011). Perfil dos usuários que procuram atendimento de urgência odontológica em uma unidade de atenção primária à saúde. Rev APS. 2011:14(1):85-92.

7. Carnut L, Figueiredo N, Goes PSA. Assessing the satisfaction level of out-of-hours dental services users in Recife. UFES Rev Odontol. 2008; 10:10-5

8. Machado GC, Daher A, Costa LR. Factors associated with no dental treatment in preschoolers with toothache: a cross-sectional study in outpatient public emergency services. Int J Environ Res Public Health 2014;8;11(8):8058-68

9. Austregésilo SC, Leal MCC, Figueiredo N, Góes PSAD. The Interface between Primary Care and Emergency Dental Services (SOU) in the SUS the interface between levels of care in oral health. Ciênc Saúde Colet. 2015 20(10):3111-20. https://doi.org/10.1590/1413-812320152010.12712014

10. Rios LE, Queiroz MG. Perception of Dentists about the Functioning of Emergency Public Dental Services. Pesq Bras Odontoped Clin Integr 2017; 17(01): e3019. https://doi.org/10.4034/PBOCl.2017.171.04

11. Fonseca DAVD, Mialhe FL, Ambrosano GMB, Pereira AC, Meneghim MDC. Influence of the organization of primary care and the socio-demographic characteristics of the population on the demand for municipal emergency dental care. Ciênc Saúde Colet. 2014;19(1):269-78. https://doi. org/10.1590/1413-81232014191.2048

12. Tramini P, Al Qadi Nassar B, Valcarcel J, Gibert P. Factors associated with the use of emergency dental care facilities in a French public hospital Spec Care in Dent. 2010; 30(2): 66-71. https://doi/10.1111/j.17544505.2009.00125.x/abstract 
13. Wong NH, Tran C, Pukallus M, Holcombe T, Seow WK. A three-year retrospective study of emergency visits at an oral health clinic in southeast Queensland. Aust Dent J. 2012;57(2):132-7. https://doi.org/10.1111/ j.1834-7819.2012.01688.x

14. Trikhacheva A, Page M, Gault H, Ochieng R, Barth BE, Cannon CM Shakhnovich O, Engelman KK. Dental-related Emergency Department Visits and Community Dental Care Resources for Emergency Room Patients. KS J Med. 2015;8(2):61-72.

15. Cachovan G, Phark JH, Schön G, Pohlenz P, Platzer U. Odontogenic infections: an 8-year epidemiologic analysis in a dental emergency outpatient care unit. Acta Odontol Scand. 2013;71(3-4):518-24. https:// doi.org/10.3109/00016357.2012.696694

16. Verma S, Chambers I. Dental emergencies presenting to a general hospital emergency department in Hobart, Australia. Aust Dent J. 2014;59(3): 329-33. https://doi.org/10.1111/adj.12202

17. Oliveira FAM, Oliveira MG, Orso VA, Oliveira VR. Dentoalveolar Traumatism: Literature Review. Rev cir traumatol buco-maxilo-fac. 2004;4(1):15-21.

18. Freitas ABDA, Bifaroni MF, Bruzadelli RR, Barros LM. Prevalence of dental fractures at the emergency clinic of a Dentistry School. Arq Odontol. 2009; 45(4):184-90

19. Brasil. Ministério da Saúde. Departamento de Atenção Básica Coordenação Geral de Saúde Bucal. SB Brasil 2010: resultados principais. Brasília: Ministério da Saúde, 2011. http://dab.saude.gov.br/ CNSB/sbbrasil/arquivos/projeto sb2010 relatorio final.pdf

20. Lemes MGC, Peixoto MRG, Meneses IHCF, Freire MCM. Dental pain and associated factors in 2 to 4 -year-old children in Goiania. Rev bras epidemiol. 2015;18(3):630-41. https://doi.org/10.1590/19805497201500030009

21. Cavalheiro $\mathrm{CH}$, Abegg C, Fontanive VN, Davoglio RS. Dental pain, use of dental services and oral health-related quality of life in Southern Brazil. Braz oral res. 2016;30(1):e39. https://doi.org/10.1590/18073107BOR-2016.vol30.0039
22. Souza JGS, Martins AMEBL. Dental pain and associated factors in Brazilian preschoolers. Rev Paul Pediatria. 2016;34(3):336-42. https:// doi.org/10.1016/j.rppede.2016.03.002

23. Silva Jr. MF, Sousa ACC, Batista MJ, Sousa MLR. Oral health condition and reasons for tooth extraction among an adult population (20-64 years). Ciênc Saúde Colet. No prelo 2017.

24. Albuquerque YE. Treatment profile at dental urgent care clinic for children and teenagers from Faculdade de Odontologia de Araraquara (FOAr) - UNESP. Rev Odontol UNESP. 2016;45(2):115-20. https://doi. org/10.1590/1807-2577.01915

25. Campos CDC, Frazão BB, Saddi GL, Morais LA, Ferreira MG, Setúbal PCO et al. Manual prático para o atendimento odontológico de pacientes com necessidades especiais. Goiânia: Universidade Federal de GoiásFaculdade de Odontologia; 2009

26. McKenna SJ. Dental management of patients with diabetes. Dent Clin North Am. 2006; Oct;50(4):591-606. https://doi.org/10.1016/j. cden.2006.06.008

27. Robertson DP, Keys W, Rautemaa-Richardson R, Burns R, Smith AJ Management of severe acute dental infection. 2015; BMJ 350:h1300.

28. Dailey YM, Martin MV. Are antibiotics being used appropriately for emergency dental treatment? Brit Dent J. 2001:191(7). https://doi. org/10.1038/sj.bdj.4801190a

29. Rios LE, Essado REDP, Freire MCM. Tratamento restaurador atraumático: conhecimentos e atitudes de cirurgiões-dentistas do serviço público de Goiânia-GO. Rev Odontol UNESP. 2006;35(1):75-80.

30. Brasil. Ministério da Saúde. Normas e Manuais Técnicos. Caderno de Atenção Básica no.17: Saúde Bucal. Brasília: Ministério da Saúde; 2006 . 